\title{
Immunohistochemistry of the uterine cervix of rats bearing the Walker 256 tumor treated with copaiba balsam ${ }^{1}$
}

\author{
Nara Macedo Botelho ${ }^{\mathrm{I}}$, Suelen Costa Corrêa ${ }^{\mathrm{II}}$, Rodolfo Costa Lobato ${ }^{\mathrm{III}}$, Renan Kleber Costa Teixeira ${ }^{\mathrm{IV}}$, Juarez Antônio Simões \\ Quaresma $^{\mathrm{V}}$ \\ IPhD, Associate Professor, Department of Especialized Health, UEPA, Para, Brazil . Conception and design of the study, critical revision, final approval \\ of the manuscript. \\ ${ }^{I I M D, ~ D e p a r t m e n t ~ o f ~ P e d i a t r i c, ~ U E P A, ~ P a r a, ~ B r a z i l . ~ A c q u i s i t i o n ~ a n d ~ i n t e r p r e t a t i o n ~ o f ~ d a t a, ~ m a n u s c r i p t ~ w r i t i n g . ~}$ \\ IIIMD, Department of Surgery, UEPA, Para, Brazil. Acquisition and interpretation of data, manuscript writing. \\ ${ }^{\mathrm{IV}}$ Graduate student, UEPA, Para, Brazil., Biostatic analysis and manuscript writing. \\ ${ }^{\vee} \mathrm{PhD}$, Associate Professor, Coordinator of the Immunopathology Laboratory, Center of Tropical Medicine, UFPA, Para, Brazil. Histological analysis, \\ critical revision.
}

\begin{abstract}
PURPOSE: To investigate the immunohistochemistry of the uterine cervix of 20 Wistar rats (Rattus norvegicus) bearing the Walker 256 tumor, treated with copaiba oil (Copaifera officinalis).

METHODS: The animals were grouped into four subgroups, with five rats each: the GCT and GCopT received distilled water and topically copaiba, respectively, while the GCG and GCopG received distilled water and copaiba by gavage, respectively. The substances were administered for nine days. On the $12^{\text {th }}$ day, after euthanasia, the tumor pieces were sent to the identification of $\mathrm{T} \mathrm{CD} 4^{+}, \mathrm{T} C D 8^{+}$ and Natural Killer cells.
\end{abstract}

RESULTS: It was found that the pattern of expression for specific markers of phenotypes of cells involved in tumor immune response was similar in all groups, regardless the administration way of copaiba oil (topical or gavage).

CONCLUSION: Copaiba balsam, administered either topically or by gavage, did not alter the pattern of tumor immune response in rats bearing Walker 256 Tumor.

Key words: Carcinoma 256, Walker. Immunohistochemistry. Cervix Uteri. Rats. 


\section{Introduction}

The expected number of new cases of uterine cervix cancer for Brazil, in 2012, was about $17.540^{1}$. Aiming to reduce its morbidity and mortality, new cytotoxic and hormonal drugs and biological agents have been used. However, toxicity against normal cells occurs as a major disadvantage and various cancers are resistant to these therapies, leading pharmaceutical industries to the development of new drugs ${ }^{2}$.

Meanwhile, the use of medicinal plants for therapeutic purposes is now widespread not only in Brazil but worldwide. However, only recently some public policies have been developed by the Ministry of Health to implement the use of medicinal plants and herbal medicines ${ }^{3}$. In Brazil, one of the most used plants is the Copaiba, being the best species for medicinal use: Copaifera officinalis, C. reticulata, C. langsdorfii and C. multijuga $a^{4,5}$.

Considering that the copaiba is widely used by Amazonian population in the treatment of gynecological cancers, including vagina and uterine cervix cancers, and the fact that there are few scientific studies that evaluate the oil effect on the local immune system, it was proposed an immunohistochemistry study to examine the uterine cervix of rats bearing the Walker 256 tumor treated with copaiba oil (Copaifera officinalis) ${ }^{6}$.

Therefore, the objective of this study was to evaluate the local immunity of the cervix of rats bearing the tumor Walker 256 treated with copaiba oil (Copaifera officinalis) by gavage and topical application, and describe the pattern of immune response to the tumor by immunostaining of anti-CD4 +, anti-CD8 + and natural Killer (NK) cells, in tissues of the uterine cervix of these rats.

\section{Methods}

Before the start of the project, it was approved by the Ethics Committee in the Use of Animals of the State University of Para (UEPA). This study used the copaiba oil species Copaifera officinalis, supplied by Brasmazon, previously submitted to a physicochemical analyze to define its composition. It was used saline $0.9 \%$ as the maintaining tumor substance and distilled water as a negative control.

Twenty virgins female Wistar rats (Rattus norvegicus) were used, weighing between 180 - 250 grams, provided from the Evandro Chagas Institute (Belem-PA), adapted to the Laboratory of Experimental Surgery, State University of Para, for fifteen days before the beginning of the experiment, kept in a controlled environment, with food and water ad libitum.
The animals were randomized into four study groups, with five animals each:

-Topical Control Group (GCT): Rats treated with distilled water by topical application to the vagina at a dose of $0.3 \mathrm{ml}$;

-Topical Copaíba Group (GCopT): Rats treated with copaiba oil by topical application to the vagina at a dose of $0.3 \mathrm{ml}$;

-Gavage Control Group (GCG): Rats treated with distilled water by gavage at a dose of $4.8 \mathrm{~m} / \mathrm{kg}$;

-Gavage Copaíba Group (GCopG): Rats treated with copaiba oil by gavage at a dose of $4.8 \mathrm{ml} / \mathrm{kg}$.

All animals underwent bilateral oophorectomy ${ }^{7}$, and tumor inoculation in the uterine cervix on day 0 of the experiment ${ }^{8}$. From day 3 to day 11, the substances were administered to their respective groups. On day 12, euthanasia was performed, with resection of the uterine cervix, the tumors were extracted entirely and weighed, and after sent for histological and immunohistochemical examination, with immunostaining of CD4+ T lymphocytes, CD8+ T lymphocytes and Natural Killer (NK) cells.

The Kruskal-Wallis test was used for compare de weigh of the tumor in each group, one-way ANOVA was used for compare the number of cells of the tumor and the number of CD4+ T lymphocytes, CD8+ T lymphocyte and Natural Killers cells according to each group. $\mathrm{p}$ values less than 0.05 were taken to indicate statistical significance.

\section{Results}

During the 12 days, no animals died. In all animals a tumor mass were identified in the region of tumor implantation and is not identified macroscopically mestastases or local tumor invasion.

Regarding the tumor weight, this was $2.25 \pm 1.09$ in TCG, $2.38 \pm 1.18$ in GCG, $2.28 \pm 1.52$ in GCopT e $4.01 \pm 2.05$ in GCopG, showing statistically difference between the GCopG and the other groups $(\mathrm{p}<0.05)$.

Histological analysis with Hematoxylin and eosin (Figures 1 and 2) demonstrated that the tumor has invaded all the layers of the cervix forming an agglomeration of dispersed cells without some characteristic form. The amount of cells present in GCopG and GCopT were lower compared to the control groups ( $p<0.05)$, no statistically significant differences present between them. 


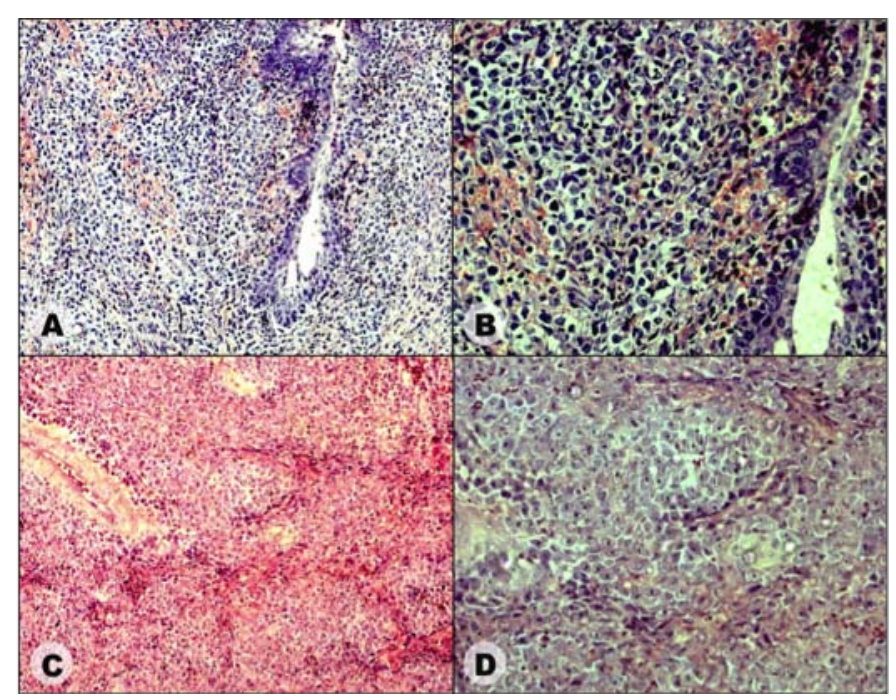

FIGURE 1 - Histopathology of the uterine cervix of rats. A. Lower magnification and B greatest increase from GCopG; C. Lower magnification and $\mathbf{D}$ greatest increase from GCG.

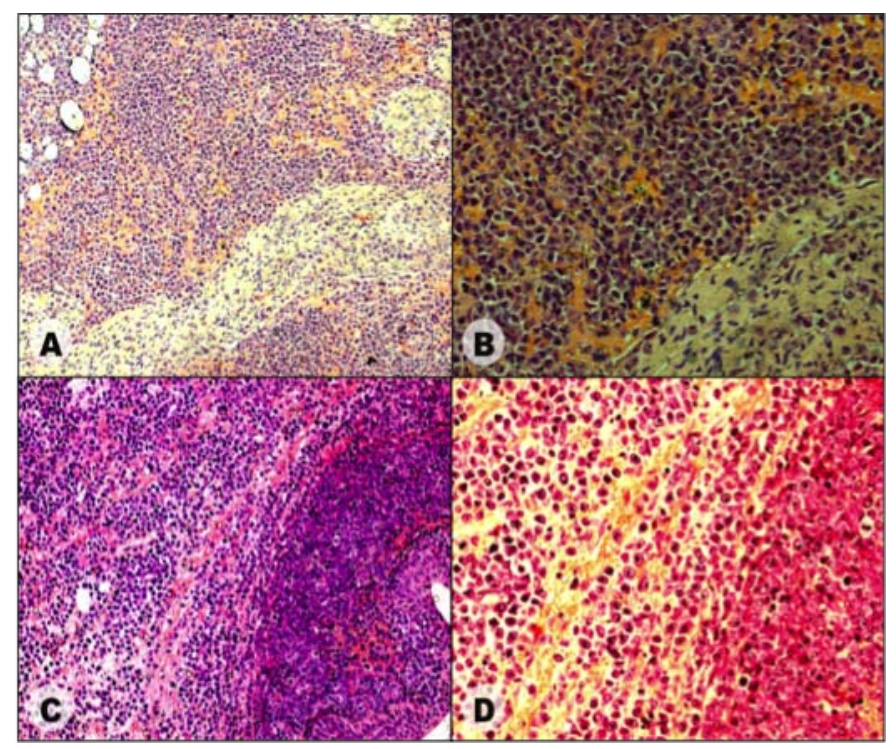

FIGURE 2 - Histopathology of the uterine cervix of rats. A. Lower magnification and $\mathbf{B}$ greatest increase from GCopT; C. Lower magnification and $\mathbf{D}$ greatest increase from GCT.

Regarding the analysis of immunohistochemistry (Figure $3)$, there was no difference between groups studied in relation to amount of immuno-labeled cells $(\mathrm{p}>0.05)$. The Table 1 shows the averages of $\mathrm{CD}^{+} \mathrm{T}$ lymphocytes, $\mathrm{CD} 8^{+} \mathrm{T}$ lymphocyte and Natural Killers cells according to each group.

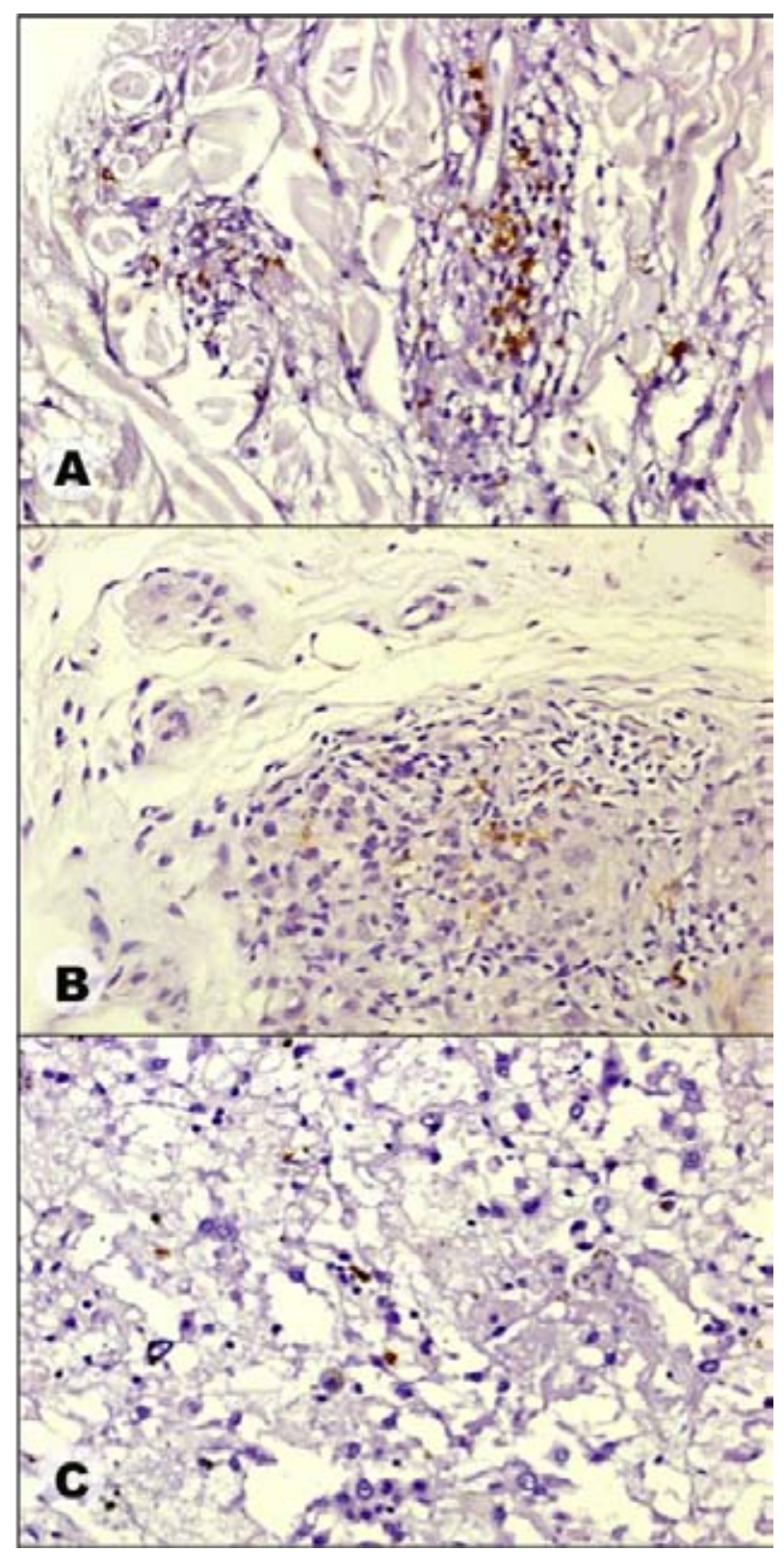

FIGURE 3 - Immunohistochemical of the uterine cervix of rats bearing the Walker 256 tumor. A. CD4 ${ }^{+}$T lymphocytes. B. CD ${ }^{+}$T lymphocyte. C. Natural Killers cells.

TABLE 1 - Averages of CD4 ${ }^{+} \mathrm{T}$ lymphocytes, $\mathrm{CD} 8^{+} \mathrm{T}$ lymphocyte and Natural Killers cells according to each group.

\begin{tabular}{cccc}
\hline Group & \multicolumn{3}{c}{ Cell } \\
& $\begin{array}{c}\mathrm{CD}^{+} \mathrm{T} \\
\text { lymphocytes }\end{array}$ & $\begin{array}{c}\text { CD }{ }^{+} \mathrm{T} \\
\text { lymphocyte }\end{array}$ & $\begin{array}{c}\text { Natural } \\
\text { Killers }\end{array}$ \\
\hline GCG & $41 \pm 5.96$ & $12 \pm 3.11$ & $8 \pm 4.55$ \\
GCT & $42 \pm 6.62$ & $10 \pm 5.63$ & $9 \pm 3.15$ \\
GCopG & $40 \pm 7.33$ & $12 \pm 5.92$ & $8 \pm 3.73$ \\
GCopT & $41 \pm 9.41$ & $13 \pm 7.44$ & $8 \pm 5.94$ \\
\hline
\end{tabular}

Source: Research protocol

$\mathrm{p}>0.05$ (ANOVA) 


\section{Discussion}

The cancer treatment presents serious difficulties especially when it is in advanced stages, where there is no effective treatment for this disease. Because of this fact has been tested several alternatives seeking a significant anti-tumor effect, like ultrasound thermotherapy techniques ${ }^{9}$ and use of medicinal plants, such as copaiba ${ }^{5}$, green tea ${ }^{10}$ and Agaricus brasiliensis ${ }^{11}$.

Copaiba oil is coming from the trunk of trees Copaiferas, being widely used by the population due to various properties attributed to these, some of which are scientifically proven ${ }^{6,12,13}$. However administered systemically stimulated growth of Walker 256 tumor inoculated into the vagina and cervix, probably because their properties similar to glucocorticoids, which when present in high doses immunosuppressive effect ${ }^{5}$. This finding stimulated this study that sought to identify the effect of oil of copaiba in the immune system of mice inoculated with walker tumor.

The immune response identified in the four groups was similar showing a predominance of $\mathrm{CD}^{+}$response. This type of response is more prepoderante in low-grade lesions, with a significant presence of $\mathrm{CD}^{+}$lymphocyte (lymphocytic) is characteristic of tumors with a high degree of dissemination ${ }^{14}$, a fact that is not common in the Walker tumor. The natural killer cells are important in initiation of tumor development, promoting lysis of tumor cells, the tumor but their development has resistance of these cells, with this decrease in tumor development ${ }^{15}$.

Changes in the number of these cells are highly relevant in tumor evolution, and the amount of decrease in $\mathrm{CD}^{+}$cells is associated with increased survival and decreased cancer cachexia $^{16,17}$. And in patients with $\mathrm{CD}^{+}$lymphocyte deficiency have greater malignant tumors and metastases ${ }^{18}$.

The GCopG showed a stimulation of tumor growth, but have an immune response similar to the other groups. This may have occurred because the oil copaiba have acted in the early stages of the immune response by reducing the amount of cell natural killer or may have acted decreasing function of cells $\mathrm{CD}^{+}$or/and $\mathrm{CD}^{+}$, necessitating further research studies to elucidate this mechanism by studying immune function in a shorter period of time and checking the amount of cytokines such as tumor necrosis factor and interleukins.

\section{Conclusion}

Copaiba oil (Copaifera officinalis), administered by gavage or topically, did not alter the pattern of tumor immune response in rats bearing Walker 256 tumor.

\section{References}

1. INCA. Estimativa 2012. Incidência de Câncer no Brasil. Disponível em: http://www.inca.gov.br/estimativa/2012/. Acesso em: 27 jan. 2013.

2. Cannistra SA, Niloff JM. Cancer of the uterine cervix. N Engl J Med.1996;334(16):1030-7.

3. Veiga Junior VF. Estudo do consumo de plantas medicinais na Região Centro-Norte do estado do Rio de Janeiro: aceitação pelos profissionais de saúde e modo de uso pela população. Rev Bras Farmacogn. 2008;18(2):308-13.

4. Santini R, Brard E. Diveloppement spatio-temporel de la tumeur de Walker implantie dans la paroi gastrique du rat Wistar. C R Seances Soc Biol Fil. 1976;170(6):1239-42.

5. Brito NMB, Brito MVH, Carvalho RKV, Matos LTMB, Lobato RC, Correa SC, Brito RB. The effect of copaiba balsam on Walker 256 carcinoma inoculated into the vagina and uterine cervix of female rats. Acta Cir Bras. 2010;25(2):176-80.

6. Garcia RF, Yamaguchi MH. Óleo de copaíba e suas propriedades medicinais: revisão bibliográfica. Saúde e Pesquisa. 2012;5(1):13746.

7. Brito NMB, Carvalho RKV, Matos LTMB, Lobato RC, Correa SC, Brito RB. The ooforectomy on Walker 256 tumor inoculated into the vagina and uterine cervix of female rats. Acta Cir Bras. 2009;24(1):26-9.

8. Brito NMB, Brito MVH, Carvalho RKV, Matos LTMB, Veloso TS, Vasconcelos DM, Brito RB. Experimental inoculation model of Walker 256 carcinoma into vagina and cervix uteri of female rats. Acta Cir Bras. 2007;22(6):495-8.

9. Morano JACOD, Cordeiro N, Guimarães SB, Jamacaru FVF, Moraes Filho MO. Experimental model of ultrasound thermotherapy in rats inoculated with Walker-236 tumor. Acta Cir Bras. 2011;26(1):53-6.

10. Ponte MF, Targino TSS, Mota MAL, Landim JSP, Ribeiro TR, Soares FP, Pereira MRP, Silva SL, Silva SFR. Growth inhibition of Walker carcinosarcoma 256 with alcoholic extract of green tea leaves (Camellia sinensis). Acta Cir. Bras. 2012;27(9):634-8.

11. Jumes FMD, Lugarini D, Pereira ALB, Oliveira A, Christoff AO, Linde GA, Valle JS, Colauto NB, Acco A. Effects of Agaricus brasiliensis mushroom in Walker-256 tumor-bearing rats. Can J Physiol Pharmacol. 2010;88(1):21-7.

12. Lima AF, Lima JFJFM. Utilização medicinal do óleo de copaíba: aspectos históricos e estudos atuais. Pós em revista. 2012;5(1):3326.

13. Botelho NM, Teixeira RKC, Yamaki VN, Silveira EL. Efeito do óleo de copaíba intravaginal no tumor de Walker 256 inoculado na vagina e útero de ratas. Rev Para Med. 2012;26(3):7-15.

14. Alves DB, Tozetti IA, Gatto FA, Cassandri F, Ferreira AMT, Fernandes CES, Falção GR, Scapulatempo IDL, Padovani CTJ, Abdo MAGS. Linfócitos CD4, CD8 e células NK no estroma da cérvice uterina de mulheres infectadas pelo papilomavírus humano. Rev Soc Bras Med Trop. 2010;43(4):425-9.

15. Satam MN, Suraiya JN, Nadkarni JJ. Natural killer and antibodydependent cellular cytotoxicity in cervical carcinoma patient. Cancer Immunol Immunother. 1986;23:56-9.

16. Pizato N, Bonatto S, Piconcelli M, de Souza LM, Sassaki GL, Naliwaiko K, Nunes EA, Curi R, Calder PC, Fernandes LC. Fish oil alters T-lymphocyte proliferation and macrophage responses in Walker 256 tumor-bearing rats. Nutrition. 2006;22(4):425-32.

17. Degasperi GR, Zecchin KG, Borecký J, Cruz-Höfling MA, Castilho RF, Velloso LA, Guimaraes F, Vercesi AE. Verapamil-sensitive Ca2+ channel regulation of Th1-type proliferation of splenic lymphocytes induced by Walker 256 tumor development in rats. Eur J Pharmacol. 2006;549(1-3):179-84. 
18. Palefsky JM. Human papillomavirus infection and anogenital neoplasia in human immunodeficiency virus-positive men and women. J Natl Cancer Inst Monogr. 1998;28:15-20.

\section{Acknowledgments}

To Bruna Kuroki Gonçalves, Lia Tavares de Moura Brasil Matos and Rita de Kássia Vidigal Carvalho for the final interpretation of data, involved in technical procedures and collection of study informations.

\section{Correspondence:}

Nara Macedo Botelho

Travessa Padre Eutíquio, 2264

66033-000 Belém - PA Brasil

Tels.: (55 91)3223-3609 / 8854-8896

narambotelho@gmail.com

Received: October 23, 2012

Review: December 21, 2012

Accepted: January 24, 2013

Conflict of interest: none

Financial source: Para Research Foundation (FAPESPA).

${ }^{1}$ Research performed at Laboratory of Experimental Surgery, State University of Para (UEPA) and Immunopathology Laboratory, Center of Tropical Medicine, Federal University of Para (UFPA), Brazil. 